\title{
A New Family of Ru Complexes for Water Oxidation
}

Ruifa Zong and Randolph P. Thummel*

\section{Supporting Information}

\section{Experimental Section}

The ${ }^{1} \mathrm{H}$ NMR spectra were obtained on a General Electric QE-300 spectrometer at 300 MHz. Chemical shifts were reported in parts per million relative to TMS. UV-Vis spectra were recorded on a Lambda 3B spectrophotometer. All spectra were corrected for the background spectrum of the solvent. Cyclic voltammetric (CV) measurements were carried out with a Bioanalysis BAS Epsilon Electroanalytical System using a one-compartment cell equipped with a glassy carbon working electrode, a saturated calomel reference electrode (SCE), and a Pt wire as the auxiliary electrode. An acetonitrile solution of $\mathrm{TBA}\left(\mathrm{PF}_{6}\right)(0.1 \mathrm{M})$ in a tube with a porous glass frit on one end was used between the SCE electrode and the sample solution. The redox potential for ferrocene $(0.42 \mathrm{~V})$ was measured separately under identical conditions. Mass spectra were obtained on a Thermo Finnigan LCQ Deca XP Plus with Surveyor LC-MS. Melting points were measured on a Thomas Hoover capillary melting point apparatus and are not corrected. The 3,6-di-(6'-[1",8"-naphthyrid-2"-yl]-pyridin-2'-yl)pyrazine (1), ${ }^{1} 2$ aminonicotinaldehyde, ${ }^{2}$ and 4-t-butyl-2,6-diacetylpyridine ${ }^{3}$ were prepared according to published procedures. Elemental analyses were carried out by QTI, P.O. Box 470, Whitehouse, NJ 088880470 .

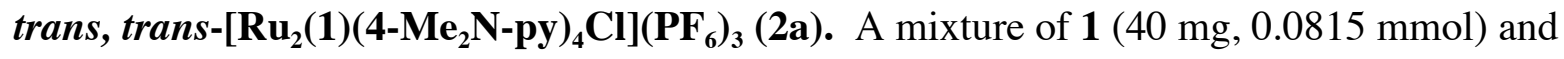
$\left[\mathrm{RuCl}_{2}(\mathrm{DMSO})_{4}\right](97 \mathrm{mg}, 0.20 \mathrm{mmol})$ in $\mathrm{EtOH}(40 \mathrm{~mL})$ and $\mathrm{CH}_{2} \mathrm{Cl}_{2}(2 \mathrm{~mL})$ was refluxed for $8 \mathrm{~h}$, producing a dark solution. Water $(5 \mathrm{~mL}), 4$-dimethylaminopyridine $(276 \mathrm{mg}, 2.26 \mathrm{mmol}), \mathrm{Et}_{3} \mathrm{~N}$ $(0.2 \mathrm{~mL})$, and $\mathrm{LiCl}(15 \mathrm{mg})$ were introduced. The dark mixture was refluxed for $2 \mathrm{~d}$ and then concentrated to about $5 \mathrm{~mL}$. Addition of $\mathrm{NH}_{4} \mathrm{PF}_{6}(118 \mathrm{mg}$, $0.72 \mathrm{mmol}$ ) produced a precipitate which was purified by chromatography on alumina. The column was eluted first with hexanes-acetone (1:1) to remove the impurities and the complex was recovered by eluting with acetone $(76 \mathrm{mg}, 56 \%), \mathrm{mp}>300{ }^{\circ} \mathrm{C}:{ }^{1} \mathrm{H}$ NMR (acetone- $\left.\mathrm{d}_{6}\right) \delta$ 
$10.00(\mathrm{dd}, J=4.2,1.8 \mathrm{~Hz}, 2 \mathrm{H}), 9.29$ (s, 2H), $9.10(\mathrm{dd}, J=8.1,0.9 \mathrm{~Hz}, 2 \mathrm{H}), 8.94$ (dd, $J=8.1,0.9$ $\mathrm{Hz}, 2 \mathrm{H}), 8.91(\mathrm{~d}, J=8.7 \mathrm{~Hz}, 2 \mathrm{H}), 8.82(\mathrm{dd}, J=8.1,2.1 \mathrm{~Hz}, 2 \mathrm{H}), 8.74(\mathrm{~d}, J=9.0 \mathrm{~Hz}, 2 \mathrm{H}), 8.30$ $(\mathrm{t}, J=8.1 \mathrm{~Hz}, 2 \mathrm{H}), 8.21(\mathrm{dd}, J=8.1,4.5 \mathrm{~Hz}, 2 \mathrm{H}), 7.32(\mathrm{dd}, J=7.5,1.5 \mathrm{~Hz}, 2 \mathrm{H}), 5.78(\mathrm{dd}, J=$ 7.5, $1.5 \mathrm{~Hz}, 2 \mathrm{H}), 2.67$ (s, $24 \mathrm{H})$. Anal. Calcd for $\mathrm{C}_{58} \mathrm{H}_{58} \mathrm{ClF}_{18} \mathrm{~N}_{16} \mathrm{P}_{3} \mathrm{Ru}_{2} \cdot 1.5\left(\mathrm{CH}_{3}\right)_{2} \mathrm{CO}: \mathrm{C}, 43.17 ; \mathrm{H}$, 3.88; N, 12.89. Found: C, 43.67; H, 3.47; N, 12.55 .

trans, trans- $\left[\mathbf{R u}_{2}(\mathbf{1})\left(4-\mathbf{C H}_{3}-\mathbf{p y}\right)_{4} \mathbf{C l}\right]\left(\mathbf{P F}_{6}\right)_{3}(\mathbf{2 b})$. The same procedure as described for $\mathbf{2 a}$ was followed, using 1 (31.4 mg, $0.064 \mathrm{mmol})$, [ $\left.\mathrm{RuCl}_{2}(\mathrm{DMSO})_{4}\right]$ (73.0 mg, $\left.0.15 \mathrm{mmol}\right)$, and 4picoline $(0.3 \mathrm{~mL}, 3.08 \mathrm{mmol})$ to afford $\mathbf{2 b}(43 \mathrm{mg}, 44 \%), \mathrm{mp}>300{ }^{\circ} \mathrm{C}:{ }^{1} \mathrm{H} \mathrm{NMR}$ (acetone- $\left.\mathrm{d}_{6}\right) \delta$ $10.02(\mathrm{dd}, J=5.4,2.1 \mathrm{~Hz}, 2 \mathrm{H}), 9.38(\mathrm{~s}, 2 \mathrm{H}), 9.16$ (d, $J=7.2 \mathrm{~Hz}, 2 \mathrm{H}), 8.92$ (d, $J=7.2 \mathrm{~Hz}, 2 \mathrm{H})$, $8.91(\mathrm{~d}, J=9.0 \mathrm{~Hz}, 2 \mathrm{H}), 8.82(\mathrm{dd}, J=8.1,1.8 \mathrm{~Hz}, 2 \mathrm{H}), 8.68(\mathrm{~d}, J=8.7 \mathrm{~Hz}, 2 \mathrm{H}), 8.37(\mathrm{t}, J=8.1$ $\mathrm{Hz}, 2 \mathrm{H}), 8.21(\mathrm{dd}, J=8.0,3.8 \mathrm{~Hz}, 2 \mathrm{H}), 7.88(\mathrm{dd}, J=8.2,1.2 \mathrm{~Hz}, 2 \mathrm{H}), 6.50(\mathrm{~d}, J=8.1 \mathrm{~Hz}, 2 \mathrm{H})$,

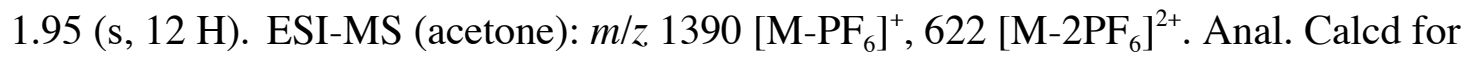
$\mathrm{C}_{54} \mathrm{H}_{46} \mathrm{ClF}_{18} \mathrm{~N}_{12} \mathrm{P}_{3} \mathrm{Ru}_{2}$ : C, 42.24; H, 3.02; N, 10.95. Found: C, 42.34; H, 2.81; N, 10.66.

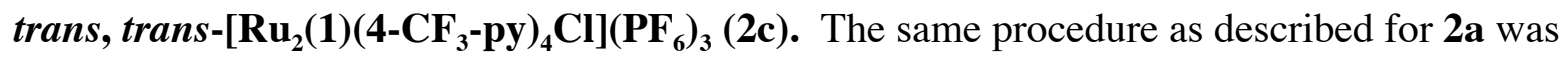
followed, using 1 (51 mg, $0.10 \mathrm{mmol}),\left[\mathrm{RuCl}_{2}(\mathrm{DMSO})_{4}\right]$ (110 mg, $\left.0.22 \mathrm{mmol}\right)$, and 4trifluoromethylpyridine (630 mg, $4.28 \mathrm{mmol})$ to afford $2 \mathrm{c}(73 \mathrm{mg}, 44 \%), \mathrm{mp}>300{ }^{\circ} \mathrm{C}:{ }^{1} \mathrm{H} \mathrm{NMR}$ $\left(\right.$ acetone-d $\left._{6}\right) \delta 10.03(\mathrm{dd}, J=4.5,1.5 \mathrm{~Hz}, 2 \mathrm{H}), 9.52(\mathrm{~s}, 2 \mathrm{H}), 9.27(\mathrm{~d}, J=8.1 \mathrm{~Hz}, 2 \mathrm{H}), 8.90(\mathrm{~d}, J=$ $8.1 \mathrm{~Hz}, 4 \mathrm{H}), 8.81(\mathrm{dd}, J=8.4,1.8 \mathrm{~Hz}, 2 \mathrm{H}), 8.60(\mathrm{~d}, J=8.7 \mathrm{~Hz}, 2 \mathrm{H}), 8.57(\mathrm{~d}, J=6.6 \mathrm{~Hz}, 8 \mathrm{H})$, $8.46(\mathrm{t}, J=8.1 \mathrm{~Hz}, 2 \mathrm{H}), 8.23(\mathrm{dd}, J=8.1,4.5 \mathrm{~Hz}, 2 \mathrm{H}), 7.02(\mathrm{~d}, J=6.6 \mathrm{~Hz}, 2 \mathrm{H})$. Anal. Calcd for $\mathrm{C}_{54} \mathrm{H}_{34} \mathrm{ClF}_{30} \mathrm{~N}_{12} \mathrm{P}_{3} \mathrm{Ru}_{2} \cdot 1.5\left(\mathrm{CH}_{3}\right)_{2} \mathrm{CO}: \mathrm{C}, 38.22 ; \mathrm{H}, 2.36 ; \mathrm{N}, 9.14$. Found: C, 38.58; H, 2.28; N, 9.72.

\section{4-tert-Butyl-2,6-di([1',8']-naphthyrid-2'-yl)pyridine (5). To a mixture of 4-t-butyl-2,6-} diacetylpyridine (225 mg, $1.02 \mathrm{mmol})$ and 2-aminonicotinaldehyde (256 mg, $2.09 \mathrm{mmol})$ in absolute ethanol $(20 \mathrm{~mL})$ was added a solution of $\mathrm{KOH}(0.05 \mathrm{~g})$ in absolute ethanol $(5 \mathrm{~mL})$. The mixture was refluxed for $6 \mathrm{~h}$ under Ar, and kept at room temperature overnight. Light yellow needles (100 mg) were collected and washed with absolute ethanol. The filtrate was concentrated to about $3 \mathrm{~mL}$ and cooled in a refrigerator. The precipitate was collected and washed with absolute ethanol $(5 \mathrm{~mL})$ to give a light yellow powder $(213 \mathrm{mg})$ for a total yield of $313 \mathrm{mg}(87$ $\%), \mathrm{mp}>270{ }^{\circ} \mathrm{C}:{ }^{1} \mathrm{H}$ NMR $\left(\right.$ methanol- $\left._{4}\right): \delta 9.07(\mathrm{dd}, J=4.2,2.0 \mathrm{~Hz}, 2 \mathrm{H}), 8.97(\mathrm{~d}, J=8.5 \mathrm{~Hz}$, 
2H), $8.97(\mathrm{~s}, 2 \mathrm{H}), 8.57(\mathrm{~d}, J=8.5 \mathrm{~Hz}, 2 \mathrm{H}), 8.50(\mathrm{dd}, J=8.2,2.0 \mathrm{~Hz}, 2 \mathrm{H}), 7.65(\mathrm{dd}, J=8.2,4.2$ $\mathrm{Hz}, 2 \mathrm{H}), 1.55$ (s, 9H).

trans-[Ru(5)(4-Me $\left.2 \mathbf{N}-\mathbf{p y})_{2}\left(\mathbf{O H}_{2}\right)\right]\left(\mathbf{P F}_{6}\right)_{2}(\mathbf{6 a})$. A solution of $5(90 \mathrm{mg}, 0.23 \mathrm{mmol})$ in absolute ethanol $(20 \mathrm{~mL})$ and an ethanolic solution $(10 \mathrm{~mL})$ of $\mathrm{RuCl}_{3}-3 \mathrm{H}_{2} \mathrm{O}(75 \mathrm{mg}, 0.29 \mathrm{mmol})$ were mixed at room temperature and the mixture was refluxed for $1.5 \mathrm{~h}$. To the mixture were added 4- $\mathrm{Me}_{2} \mathrm{~N}$-py $(244 \mathrm{mg}, 2 \mathrm{mmol})$, water $(10 \mathrm{~mL})$, and triethylamine $(0.2 \mathrm{~mL})$. The color of the mixture changed gradually from brown to green. After reflux overnight, a dark green solution was obtained. The solution was concentrated to about $10 \mathrm{~mL}$, followed by the addition of aqueous $\mathrm{NH}_{4} \mathrm{PF}_{6}$ (154 mg in $2 \mathrm{~mL}$ of water). The precipitate was filtered and washed with water. Treatment of the precipitate with acetone yielded a dark green solution, which was purified by chromatography (alumina, acetone/hexanes, 1:1) to produce green, purple, and blue fractions. The last two fractions were further purified by a second column (alumina, acetone with $1 \%$ saturated $\mathrm{KPF}_{6}$ ). The blue fraction was collected. Recrystallization from acetone and water gave dark blue crystals $(142 \mathrm{mg}, 59 \%), \mathrm{mp}>270{ }^{\circ} \mathrm{C}:{ }^{1} \mathrm{H}$ NMR (acetone- $\left.\mathrm{d}_{6}\right): \delta 9.49(\mathrm{dd}, J=4.5$, $1.8 \mathrm{~Hz}, 2 \mathrm{H}), 9.46$ (s, 1H), 9.44 (s, 1H), 9.18 (d, J=8.8 Hz, 2H), 9.18 (s, 2H), 8.93 (d, J=8.8 Hz, 2H), $8.85(\mathrm{dd}, J=8.1,1.8 \mathrm{~Hz}, 2 \mathrm{H}), 8.07(\mathrm{dd}, J=8.1,4.5 \mathrm{~Hz}, 2 \mathrm{H}), 7.30(\mathrm{dd}, J=7.0,1.4 \mathrm{~Hz}, 4 \mathrm{H})$, $6.06(\mathrm{dd}, J=7.0,1.4 \mathrm{~Hz}, 4 \mathrm{H}), 2.74(\mathrm{~s}, 12 \mathrm{H}), 1.66(\mathrm{~s}, 9 \mathrm{H})$.

trans-[Ru(5)(4-Me-py $\left.)_{2}\left(\mathrm{OH}_{2}\right)\right]\left(\mathrm{PF}_{6}\right)_{2}(6 \mathrm{~b})$. Following same procedure as described for 6a, a solution of 5 (101 mg, $0.258 \mathrm{mmol})$ in absolute ethanol $(20 \mathrm{~mL})$ and an ethanol solution $(10 \mathrm{~mL})$ of $\mathrm{RuCl}_{3}-3 \mathrm{H}_{2} \mathrm{O}(70 \mathrm{mg}, 0.267 \mathrm{mmol})$ was treated with 4- $\mathrm{CH}_{3}-$ py $(0.5 \mathrm{~mL}, 5.1 \mathrm{mmol})$, water (10 $\mathrm{mL}), \mathrm{Et}_{3} \mathrm{~N}(0.2 \mathrm{~mL})$, and $\mathrm{NH}_{4} \mathrm{PF}_{6}(145 \mathrm{mg}, 0.89 \mathrm{mmol})$ to yield a dark green solution, which was purified by chromatography (alumina, acetone/hexanes, 1:2 to 1:0) to produce yellow, green, brown and blue fractions. The blue fraction was recrystallized from acetone and water to provide dark blue crystals $(129 \mathrm{mg}, 50 \%), \mathrm{mp}>270{ }^{\circ} \mathrm{C}:{ }^{1} \mathrm{H}$ NMR (acetone- $\left.\mathrm{d}_{6}\right): \delta 9.44(\mathrm{dd}, J=4.5,2.1$ $\mathrm{Hz}, 2 \mathrm{H}), 9.13(\mathrm{~s}, 2 \mathrm{H}), 9.13(\mathrm{~d}, J=8.7 \mathrm{~Hz}, 2 \mathrm{H}), 8.90$ (d, $J=9.0 \mathrm{~Hz}, 2 \mathrm{H}), 8.79$ (dd, $J=8.1,2.4$ $\mathrm{Hz}, 2 \mathrm{H}), 8.01(\mathrm{dd}, J=7.8,4.5 \mathrm{~Hz}, 2 \mathrm{H}), 7.85(\mathrm{dd}, J=5.1 \mathrm{~Hz}, 4 \mathrm{H}), 6.75(\mathrm{~d}, J=6.3 \mathrm{~Hz}, 4 \mathrm{H}), 3.87$ (s, 6H), 1.61 (s, 6H); MS (MALDI-TOF): $m / z 985.4\left(\mathrm{M}^{+}\right)$. IR (ATR): $v=1699\left(\delta_{\mathrm{O}-\mathrm{H}}\right)$; Anal. Calcd for $\mathrm{C}_{37} \mathrm{H}_{37} \mathrm{~N}_{7} \mathrm{~F}_{12} \mathrm{OP}_{2} \mathrm{Ru}-1.5 \mathrm{C}_{3} \mathrm{H}_{6} \mathrm{O}$ : C, 46.42; H, 4.32; N, 9.13. Found: C, 45.99; H, 4.26; $\mathrm{N}, 8.95$. 
trans-[Ru(5)(4-CF $\left.-\mathbf{C F y}_{\mathbf{2}}\left(\mathrm{OH}_{2}\right)\right]\left(\mathbf{P F}_{6}\right)_{2}(\mathbf{6 c})$. Following same procedure as described for $6 \mathbf{6}$, the reaction of 5 (70 mg, $0.18 \mathrm{mmol}), \mathrm{RuCl}_{3}-3 \mathrm{H}_{2} \mathrm{O}$ (70 mg, $\left.0.267 \mathrm{mmol}\right), 4-\mathrm{CF}_{3}-$ py $(250 \mathrm{mg}, 1.70$ $\mathrm{mmol})$, water $(10 \mathrm{~mL})$, triethylamine $(0.2 \mathrm{~mL})$, and $\mathrm{NH}_{4} \mathrm{PF}_{6}(145 \mathrm{mg}, 0.89 \mathrm{mmol})$ yielded blue crystals $(38 \mathrm{mg}, 19 \%), \mathrm{mp}>270{ }^{\circ} \mathrm{C}:{ }^{1} \mathrm{HNMR}$ (acetone-d 6 ): $\delta 9.48(\mathrm{dd}, J=4.5,1.8 \mathrm{~Hz}, 2 \mathrm{H})$, $9.22(\mathrm{~d}, J=8.1 \mathrm{~Hz}, 2 \mathrm{H}), 9.21(\mathrm{~s}, 2 \mathrm{H}), 9.01(\mathrm{~d}, J=8.7 \mathrm{~Hz}, 2 \mathrm{H}), 8.86(\mathrm{dd}, J=8.1,2.1 \mathrm{~Hz}, 2 \mathrm{H})$, $8.54(\mathrm{~d}, J=6.3 \mathrm{~Hz}, 4 \mathrm{H}), 8.08(\mathrm{dd}, J=8.1,4.5 \mathrm{~Hz}, 2 \mathrm{H}), 7.30(\mathrm{~d}, J=6.6 \mathrm{~Hz}, 4 \mathrm{H}), 1.65$ (s, 6H).

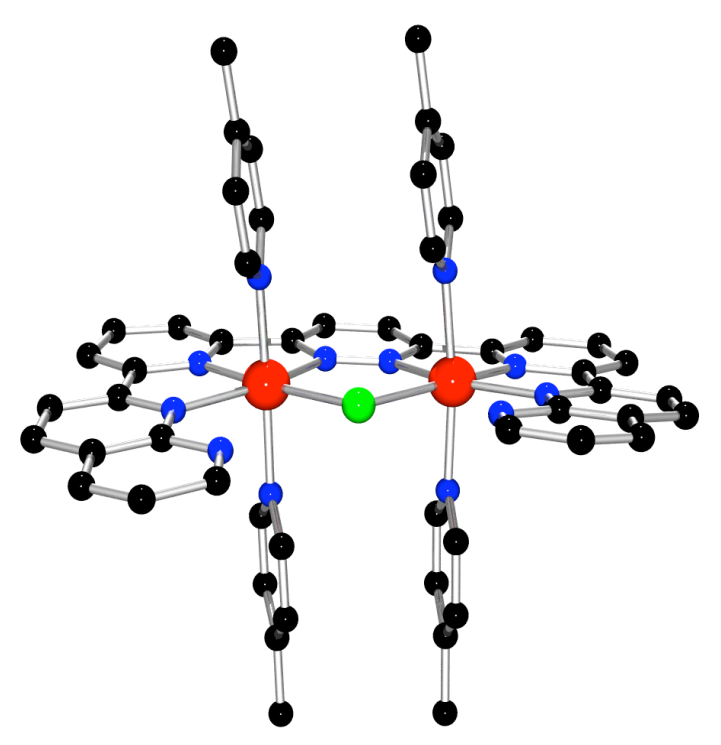

Figure S1. X-ray structure of the cation of $\mathbf{2 b}$

Oxygen evolution: The experimental setup consists of home-made $13 \mathrm{~mL}$ jacketed glass cell with a threaded neck and a capillary side-arm for catalyst injection. The cell was charged with 3 $\mathrm{mL}$ of an aqueous $.304 \mathrm{M} \mathrm{Ce}(\mathrm{IV})-\mathrm{CF}_{3} \mathrm{SO}_{3} \mathrm{H}$ solution (add $500 \mathrm{mg}$ ceric ammonium nitrate to 3 $\mathrm{mL}$ aqueous $\mathrm{CF}_{3} \mathrm{SO}_{3} \mathrm{H}$ adjusted to $\mathrm{pH} 1.0$ ), magnetically stirred at $24{ }^{\circ} \mathrm{C}$. An acetonitrile solution of the catalyst $(0.01 \mathrm{M}$ in $\mathrm{Ru}, 0.10 \mathrm{~mL})$ was added by syringe. For catalyst $\mathbf{2 b}$, the solution was $0.001 \mathrm{M}$ in Ru. The evolved oxygen was measured with an YSI 5331 standard oxygen probe mounted in the threaded opening of the cell and connected to a YSI 5300A oxygen monitor. Communication between a PC and the oxygen monitor was accomplished with a program called Bytewedge and the readings of $\% \mathrm{O}_{2}$ vs. time were sent every second to the PC 
where the data were saved in a file. The first order rate constant was obtained by an exponential fit of the observed oxygen $v s$. time curve. A representative oxygen evolution curve catalyzed by $\mathbf{2 b}$ is shown in Figure S2. The oxygen probe was periodically calibrated by injecting known volumes of pure oxygen to establish a correction curve.

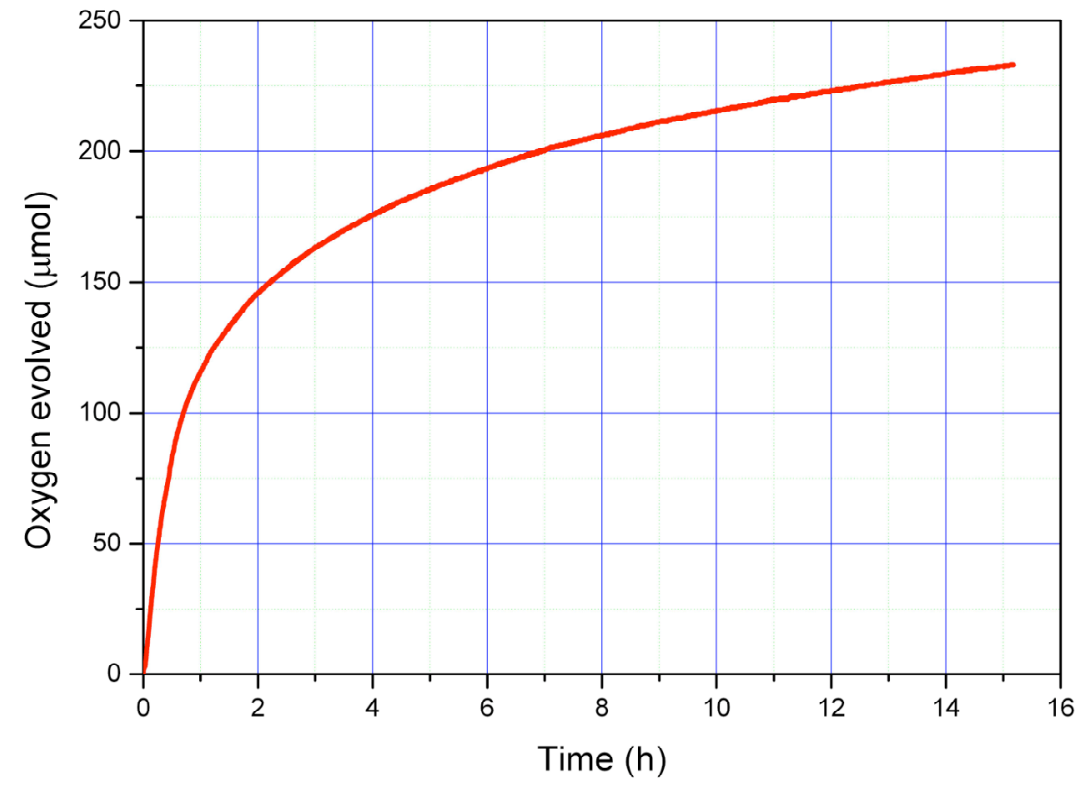

Figure S2. Oxygen evolution vs. time for $\mathbf{2 b}$.

\section{References}

1. Zong, R.; Hammitt, R.; Wang, D.; Thummel, R. P. manuscript in preparation.

2. Majewicz, T. G.; Caluwe, P. J. Org. Chem. 1974, 39, 720-721.

3. Nueckel, S.; Burger, P. Organometallics 2001, 20, 4345-4359. 